\section{Tax breaks for broadleaved trees}

Multipurpose use is an increasingly popular catchword among natural resource managers, implying that seemingly conflicting demands on a resource, such as a trout stream and a hydropower dam, can in reality be harmonized. The concept is the lynchpin of the British Forestry Commission's (FC) new broadleaved woodlands policy, intended to give enough tax relief and grant aid to make growing broadleaved trees profitable. These incentives, according to the commission, will persuade landowners voluntarily to manage now-neglected broadleaved woodlands and also to plant new stands, thus providing a habitat for native British wildlife and soothing the British eye for beauty, which prefers a native oak to an exotic conifer.

The principal criticism of the new programme, from foresters and conservation groups alike, is that broadleaves are hard to grow and that the commission's system of advisers for helping landowners will be understaffed and underbudgeted. The commission, on the other hand, claims the government is committed to the advisory system and will review it in 3-5 years.

One-third of Britain's productive timberland $(566,000$ hectares) is planted in broadleaves, with virtually all of that in the lowlands and in private hands. Broadleaves management, therefore, is clearly a question of motivating the private sector. Neither broadleaves nor conifers are selfsupporting timber industries, according to Mr David Conder of the Council for the Protection of Rural England; therefore, broadleaves, for which there is "an environmental and recreational preference", should be given the more attractive tax break.

Conifers and broadleaves, however, are more dissimilar than Mr Conder suggests: the latter grow more slowly, need more room and produce less usable timber. $\mathrm{Mr}$ Esmond Harris of the Royal Forestry Society of England and Wales claims, for example, that Corsican pine stands in the Forest of Dean are three to four times more valuable than the broadleaves grown there.

Private landowners would like to see a profit within their own lifetime, so research by the Forestry Commission and private interests into higher-quality and faster-growing broadleaves is as important as new tax and grant schemes. Mr Harris points to plastic tubes that shelter young broadleaves, helping them grow four times faster than by conventional methods and halving the $120-150$ years many broadleaves need to mature. Making broadleaves a commercial success, says Mr Harris, is the key for conservation efforts: wildlife needs can then be incorporated into productive woodlands rather than forcing land to be set aside just

\section{for habitat.}

Part of the growing public interest in broadleaves is a backlash against conifers, which it is claimed do not support ancient woodland plants, create acidity on the soil's surface and leach nutrients from the soil. Mr Mark Anderson, forest ecologist at the commission, says conifers do not deserve such blackballing. He points to the cycle of canopy closure and species differences in litter properties - whether the leaves pack down and rot or not - as the crucial elements in plant colonization. Conifers do acidify surface soil, particularly in the uplands where the soil has little buffering capacity, but these properties peak and trough and then revert to approximately their initial values by the end of the rotation. And finally, tannin does
Tokyo

GIANT clam colonies, first reported from the deep sea off Japan only two months ago (Nature 315,$624 ; 1985$ ) are now popping up right, left and centre, from as little as a kilometre off the Izu Peninsula to a depth of over 5,000 metres in the Japan Trench. Discovery of the colonies provides a golden opportunity to study these strange organisms, believed to draw their energy from a source in the Earth beneath them rather than the Sun above.

Days after the French submersible Nautile located giant clam colonies at a record depth of $3,840 \mathrm{~m}$ in the mouth of the Tenryu Canyon off the Pacific coast, Japan's submersible Shinkai 2000 found similar colonies in Sagami Bay at a depth of $1,300 \mathrm{~m}$, a mere stone's throw away from the hot spring resort town of Itoh on the Izu Peninsula. A month later, Nautile shattered its own record with the discovery of another clam colony at $5,640 \mathrm{~m}$ on the steep inner wall of the Japan Trench, immediately opposite the First Kashima seamount.

This discovery was made by Kantaro Fujioka of the Ocean Research Institute, University of Tokyo, during the second leg of the Franco-Japanese project Kaiko, and Kazuaki Nakamura of the Earthquake Research Centre, University of Tokyo. The colony, measuring two by one metres, consists of banana-shaped clams up to about $15 \mathrm{~cm}$ in length which have tentatively been identified as Calyptogena sp.; they are stacked together forming an imbrication parallel to the long axis of the colony.

As in the case of the Tenryu Canyon colonies, a positive temperature anomaly of about $0.3^{\circ} \mathrm{C}$ was associated with the colony which occurred in a slight depressled jointly by Guy Pautot of IFREMER wash out of conifer leaves, chemically associate with soil nutrients and wash to lower levels; but this behaviour happens primarily in poor soil and is also associated with broadleaves.

The upland conifer issue, according to $\mathrm{Mr}$ John Andrews of the Royal Society for the Protection of Birds, comes down to a conflict between agriculture and forestry. As agriculture has been allowed more hill land, forest plantations have been pushed further north and west into poorer and poorer land that is also valuable bird habitat. There the trees do not grow large and are subject to considerable windfall, which means there are no old trees for birds to drill holes in. By "moving the centre of gravity of foresty downhill", says $\mathrm{Mr}$ Andrews, the Forestry Commission could grow better trees while leaving the windswept moors with the poorest soils to the birds and animals that do in fact thrive there.

Elizabeth Collins

\title{
Deep-sea clams New find near Japan's coast
}

ion. There are reports that the French have found an even deeper colony during the third and final leg of Kaiko now in progress at the northern end of the Japan Trench.

The colonies off the Izu Peninsula are larger, the biggest living colony being twenty by five metres, and, like the Tenryu Canyon and Japan Trench colonies, are associated with thrust faulting caused by subduction as the Izu Peninsula riding on the Philippine plate ploughs into the rest of Japan. Clams collected by Teruaki Ishi of the Ocean Research Institute have been identified as Calyptogena soyoae by Sugura Ohta of the same institute, who also recognized in video records what appear to be vestimentiferan tube worms attached to a ledge above the clam colony.

Unfortunately, Shinkai 2000 was unable to collect specimens of the worms, which have not been found at the deeper colonies. Despite proximity to hot springs on land, Dr Ohta does not think the colonies off Izu derive their energy from hot vents as at mid-ocean spreading ridges but, rather, suspects that they are sustained by old seawater "squeezed" out along fault planes by subduction.

The find off Izu is well within the 2,000m depth range of Shinkai 2000 and lies very close to land, opening up the possibi lity of regular in situ experiments. A deeper-going Japanese submersible capable of examining the Japan Trench colonies is at the design stage. Although the new submersible was originally intended to have a depth limit of 6,000 metres as in the case of Nautile, an advisory body to the Science and Technology Agency recommended last month that this should be increased to 6,500 metres, thereby allowing access to all but the deepest trench basins off Japan. David Swinbanks 